\title{
Correction to: Priming approaches to improve the efficacy of mesenchymal stromal cell-based therapies
}

\author{
Nádia de Cássia Noronha ${ }^{1,2}$, Amanda Mizukamii , Carolina Caliári-Oliveira ${ }^{3}$, Juçara Gastaldi Cominal ${ }^{1,2}$, \\ José Lucas M. Rocha ${ }^{1,4}$, Dimas Tadeu Covas ${ }^{1}$, Kamilla Swiech ${ }^{1,5}$ and Kelen C. R. Malmegrim ${ }^{1,6^{*}}$
}

\section{Correction to: Stem Cell Res Ther \\ https://doi.org/10.1186/s13287-019-1224-y}

The original article [1] contained an error in the presentation of the first author's name, Nádia de Cássia Noronha. This has now been corrected.

\begin{abstract}
Author details
${ }^{1}$ Center for Cell-based Therapy, Regional Blood Center of Ribeirão Preto, Ribeirão Preto Medical School, University of São Paulo, Ribeirão Preto, Brazil. ${ }^{2}$ Graduate Program on Bioscience and Biotechnology, School of Pharmaceutical Sciences of Ribeirão Preto, University of São Paulo, Ribeirão, Preto, Brazil. ${ }^{3}$ In Situ Cell Therapy, SUPERA Innovation and Technology Park, Ribeirão Preto, São Paulo, Brazil. ${ }^{4}$ Graduate Program on Basic and Applied, Immunology, Ribeirão Preto Medical School, University of São Paulo, Ribeirão, Preto, Brazil. ${ }^{5}$ Department of Pharmaceutical Sciences, School ofPharmaceutical Sciences of Ribeirão Preto, University of São Paulo, Ribeirão, Preto, Brazil. ${ }^{6}$ Department of Clinical, Toxicological and Bromatological Analysis, School of Pharmaceutical Sciences of Ribeirão Preto, University of São Paulo, Avenida do Café, s/nº, Ribeirão Preto, SP 14010-903, Brazil.
\end{abstract}

Received: 10 May 2019 Revised: 10 May 2019 Accepted: 10 May 2019 Published online: 17 May 2019

\section{Reference}

1. Noronha NC, et al. Priming approaches to improve the efficacy of mesenchymal stromal cell-based therapies. Stem Cell Res Ther. 2019;10:131 https://doi.org/10.1186/s13287-019-1224-y.

\footnotetext{
* Correspondence: kelenfarias@fcfrp.usp.br

${ }^{1}$ Center for Cell-based Therapy, Regional Blood Center of Ribeirão Preto, Ribeirão Preto Medical School, University of São Paulo, Ribeirão Preto, Brazil ${ }^{6}$ Department of Clinical, Toxicological and Bromatological Analysis, School of Pharmaceutical Sciences of Ribeirão Preto, University of São Paulo, Avenida do Café, s/nº Ribeirão Preto, SP 14010-903, Brazil

Full list of author information is available at the end of the article
}

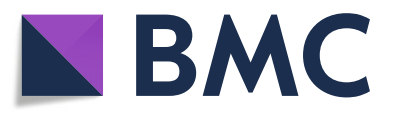

(C) The Author(s). 2019 Open Access This article is distributed under the terms of the Creative Commons Attribution 4.0 International License (http://creativecommons.org/licenses/by/4.0/), which permits unrestricted use, distribution, and reproduction in any medium, provided you give appropriate credit to the original author(s) and the source, provide a link to the Creative Commons license, and indicate if changes were made. The Creative Commons Public Domain Dedication waiver (http://creativecommons.org/publicdomain/zero/1.0/) applies to the data made available in this article, unless otherwise stated. 